\title{
He Died for Our Sins (in a Contextually-Sensitive Way)
}

\author{
Joshua C. Thurow \\ University of Texas at San Antonio
}

\begin{abstract}
How does Jesus's death atone for human sin? Traditional answers to this question face a challenge: explain how Jesus's death plays an important and distinctive role in atoning for human sin without employing problematic philosophical or moral assumptions. I present a new answer that meets the challenge. In the context of the Jewish sacrificial background, the blood of a pure victim can communicate the washing away of sins. Jesus's death atones because through it his blood, and then his resurrection, can communicate the washing away of sins and thus that God has accepted his work of atonement.
\end{abstract}

Christians believe that the problem of human sin has been resolved through the atoning work of Jesus. Furthermore, Jesus's death on the cross is a crucial element of his atoning work (Eph. 1:7; Col. 2:14). This paper will focus on the following question: how does Jesus's death atone for human sin? The Church, broadly speaking, has issued very little doctrine on this question. The Nicene Creed, for instance, merely notes that "for our sake he was crucified under Pontius Pilate." 1 The silence of the Church on this matter has been filled with the voices of Christian thinkers from the patristic age through today. Although there are now various theories of atonement, these theories have struggled to explain how Jesus's death crucially and distinctively atones for human sin.

In this paper I shall first argue that theories of atonement face a challenge in trying to explain how Jesus's death atones for human sin. I will then argue that several prominent theories of atonement fail to overcome the challenge. Having raised this challenge, in the second part of the paper I will attempt to overcome it. Drawing on some recent philosophical work on atonement-in particular on the idea that the adequacy of atoning acts is context-sensitive-I will offer a new explanation of how Jesus's death atones for human sin that meets the challenge. The explanation, in short, is that because of the Jewish sacrificial background the blood of a pure victim (offered in the right sort of way with the right sort of intention) has the power to communicate the washing away of sins. Jesus's death atones because through it his blood, and then

${ }_{1}^{1}$ Translation from the USCCB. www.usccb.org/beliefs-and-teaching/what-we-believe

Journal of Analytic Theology, Vol. 9, Summer 2021

10.12978/jat.2021-9.0914-65190722

(C) 2021 Joshua C. Thurow • (C) 2021 Journal of Analytic Theology 
his resurrection, can communicate the washing away of sins and thus that God has accepted his work of atonement on the behalf of humanity.

I will not offer a comprehensive theory of atonement; much more would go into that than I can discuss here. Neither will I argue that the Christian doctrine of atonement, properly understood, should include the explanation I defend. That is a task for biblical and systematic theologians, whereas I tackle the more humble taskappropriate to the philosopher of religion or philosophical theologian-of giving a logically consistent elucidation of a theological proposition that avoids theoretical and philosophical objections. That said, the explanation is grounded in reflection on Old Testament sacrifices and New Testament use of those sacrifices to describe Jesus's work, which provides evidence that the explanation is part of the Christian doctrine of the atonement, properly understood.

Before proceeding to the challenge, a word about the concept of atonement. The concept, as I understand it and use it in this paper, is to be understood in the following generic way: to atone is to intentionally act in a way that removes a rift or division between people that is due to at least one party wronging the other, in order to achieve reconciliation. ${ }^{2}$ This notion is generic in two senses. First, it does not presuppose any particular theory of how atonement is or can be achieved. Second, the concept applies to both human-human and divine-human relationships. The latter is the concern of the Christian doctrine of Atonement, which can now be summarized as follows: in some of his deeds, Jesus acts in such a way as to remove the rift or division between humans and God that is due to human sin in order to achieve reconciliation between humans and God.

A variety of useful related notions can be defined. First, an attempt at atonement is an intentional act with the aim of atoning. Attempts may fail, and so an attempt at atonement may not atone. I will sometimes use the phrase "act of atonement," which will be understood to be synonymous with "attempt at atonement." Second, an attempt at atonement is fitting just in case it could in principle contribute to removing a rift between the actor and the victim (a rift that is due to the actor wronging the victim). Some attempts may not be fitting, and fitting attempts may fall short of fully atoning for the wrong. ${ }^{3}$ Third, an attempt at atonement is adequate just in case it is fitting and will remove the rift provided the victim is aware of the attempt and accepts it.

Three further assumptions will be made throughout this paper.

(A1) Jesus's death atones for human sin.

(A2) Human sin is the sin of humanity-the collection of all humans.

\footnotetext{
2 Beilby and Eddy (2006): 9; Daly (2009): 35; Forsyth (1910/1938): 54-8; Hodges (1955): 9-10; O'Collins (2007): 11; Paul (1960): 17-27; Riviere (1909): 2-4.

${ }^{3}$ For example, suppose a child steals his sister's favorite candy bar and offers a piece of gum as reparation. Offering the gum is a fitting, but inadequate attempt at atonement. Instead suppose the child, as reparation, offered to spread a lie about her sister's enemy. This attempt wouldn't even be fitting.
} 
I won't make any assumptions here about whether that sin is best understood as simply a mass of individual human sins or as a distinctive collective sin, or the set of both. ${ }^{4}$

(A3) Jesus's death plays an important, distinctive, and not merely ancillary role in atoning for human sin.

Other aspects of Jesus's ministry may well also play an atoning role, but Jesus's death plays an important and distinctive role. So, for example, his death can't simply be part of a life that as a whole atones for human sin. His death also can't provide just a little more of something than what other aspects of his life provide by way of atonement.

Why do I make these assumptions? First, they are common Christian assumptions. ${ }^{5}$ Second, it is in the context of these assumptions that the central question of this paper is particularly pressing. For instance, if we reject (A3) and allow Christ's death to atone in a more ancillary way, then it is much less challenging to explain how his death atones. For then we could just say that his whole holy life in service of God atones and his death is just an unfortunate part of his life because of the action of sinful humans. His death provides less of a puzzle if (A3) is rejected. But, if his death is so important for atonement, then there better be a good reason for why something so costly is so important.

\section{A Challenge}

Standard surveys often divide theories of atonement into two kinds-objective and subjective. ${ }^{6}$ Subjective theories answer our question by saying that Christ's death atones by effecting some crucial change in us-it is a model for our life, raises our sympathy to him and his mission, makes us aware of and inflamed with God's love, and the like. Christ's death atones by changing our attitudes, purposes, goals, loves, and beliefs. To be sure, when we change in these ways we change our relationship to God. Objective theories answer our question by saying that Christ's death atones by effecting some other, more objective relationship to God, such as remitting guilt or paying a punishment. Guilt provides a useful example of how the subjective and objective theories can differ. A subjective view might say that Christ's death helps me

\footnotetext{
${ }^{4}$ See Thurow (2015) and Thurow (2017) for discussion and defense of regarding Jesus as atoning for collective human sin.

${ }^{5}$ Indeed, the roots of these assumption go back to Christian scripture. For (A1), see Eph. 1:7; Col. 2:14. For (A2) see John 1:29; Rom 3:23; Eph 2:1-3, 15-6; 1Tim 2:5-6; 1Pet 3:18; 1Jn 2:2. For (A3) see the many passages that describe Jesus's death as a sacrifice or ransom for sins (a list of some is provided at the beginning of section 3 below). See also Pelikan (1978): 131-3 and references therein.

${ }^{6}$ See, for example, Aulen (1931), Beilby and Eddy (2006), MacKinnon (1966), McGrath (1992), Turner (1952). Grensted (1920) uses the roughly synonymous "God-ward" and "man-ward" terminology. The objective/subjective scheme is complicated by two matters: first, the definition of the distinction varies (Fiddes 1989: 26-28) and second, some (inspired by Aulen) add a third category-Christus Victor. The way I draw the distinction, Christus Victor counts as an objective theory. Instead of speaking of objective and subjective theories, one could (as does Fiddes, and as occasionally will I) speak of objective and subjective dimensions/elements/aspects of atonement.
} 
both to feel guilty for my sins, but also to feel forgiven and to commit to changing my life. An objective view might say that this is all well and good, but something objective needs also to be dealt with-my guilt. Feeling guilty is different from being guilty. Christ's death might subjectively swell and then reduce my feelings of guilt, but my feelings of guilt can change without affecting my being guilty. So, an objective view might say that my guilt still needs to be dealt with and that Jesus's death somehow takes away my guilt. Just to be clear: not all objective views would say that the objective state that Jesus's death addresses is guilt (likewise not all subjective theories focus on soothing felt guilt). Some objective theories instead focus on being a slave to sin, or being subject to sin, or being under the power of the devil (as do Christus Victor theories).

Moral exemplar and moral influence views are examples of subjective views. Moral exemplar views emphasize that Jesus is an example to follow. Moral influence views emphasize the more general idea that Jesus's life influences our own in various ways. Abelard is frequently charged as the archetype and father of moral exemplar views (although there is reason to dispute both charges-see Weingart 1970). Rashdall (1920) is perhaps the most well-known modern advocate of a moral influence view. Penal substitution views, advocated by Luther, Melanchthon, Calvin, Turretin, and others, ${ }^{7}$ on which by dying Christ suffers the punishment that is due to sinful humanity, are objective views. Anselm's satisfaction view is also objective since it asserts that Christ's supererogatory death enables him to either cancel or pay the debt of honor that humanity owes to God. ${ }^{8}$ As mentioned earlier, Christus Victor views are also objective because they suppose that through Christ's work the power or dominion of Satan is defeated.

Many views say that Christ's death atones in both subjective and objective ways. Indeed, every figure I'm aware of that thinks Christ's death does something objective also thinks that Christ's death does something subjective. There's good theological reason for this. In order to atone and bring about reconciliation the wrongdoer must acknowledge her wrong and at least aim at improving herself in the future. So, wrongdoers must contribute something to atonement. When dealing with their sins, people need to confess, repent, and have faith in Christ. Christ's death will at least indirectly bring about these states through grace. Thus, Christ's objective atoning work also brings about the subjective element of atonement. ${ }^{9}$ As Turner proclaims, "even the most rigidly objective doctrine of the Cross must leave room for the Imitatio Christi at least as a corollary or a consequent" $(1952,117) .{ }^{10}$ So, the

\footnotetext{
7 See Grensted (1920), ch.9 and 10 for discussion of the views of these reformation figures. Contemporary advocates of the penal view include Marshall (2007), Morris (1983), and Schreiner (2006).

${ }^{8}$ Contemporary defenders of satisfaction views include, most notably, Swinburne (1989) and Stump (2003).

${ }^{9}$ McGrath (1992: 88) accuses Christus Victor views of being purely objective. For the reasons given, I don't think this is correct. However, it might still be that Christus Victor views unacceptably deemphasize the subjective aspects.

10 The imitation of Christ and other subjective effects of Christ's work on our own attitudes and behavior is a persistent theme in the New Testament and early Christian literature (Grensted 1920; Turner 1952). See, e.g., Athanasius (1996).
} 
dispute isn't between those who think that Christ's death atones purely subjectively and those that think it atones purely objectively. The dispute is between those who think that it atones purely subjectively and those who think it atones both subjectively and objectively.

The challenge is simply this: both subjective and objective theories have a difficult time explaining how Jesus's death on the cross atones for human sin in a way that respects (A3). The difficulty is fairly clear for subjective theories. If the atoning significance of Christ's work consists simply in the subjective effects it has on sinful humans - causing us to confess, repent, love more sincerely, and change our waysthen it is far from clear how Jesus's death contributes anything important or distinctive. Surely his brave death in service of God might be particularly effective in enflaming our love, but this is a mere difference in degree. It certainly isn't necessary that Jesus die in order for us to be so motivated and we could be very strongly motivated without his death. So, on the subjective view, Jesus's death doesn't contribute anything particularly important or distinctive-it is merely a somewhat more powerful motivator.

Objective theories tend to fail to meet this challenge by falling into one of two pitfalls. Either they give an unclear explanation of how Christ's death atones in a way that respects (A3) or they give a clear explanation at the expense of importing problematic assumptions. The Christus Victor theory nicely illustrates this dilemma. According to Gregory Boyd, a defender of the Christus Victor view, "the essence" of the view is that God breaks "into human history to destroy the power of sin and rescu[e] us from the cosmic powers that keep us in bondage to $\sin ^{\prime \prime}(2006,29)$. These powers are manifested in sickness, demon-possession, personal sin, death, and corrupt social structures. Jesus's healings, exorcisms, teaching and offering of forgiveness, resurrections, and preaching against the rulers all contributed to rescuing humans. But, it is quite unclear what Jesus's death contributes. Perhaps his submission to crucifixion and resurrection together show that not even death will conquer him or his followers. That's quite an impressive manifestation of victory, but it doesn't contribute anything distinctive. He'd already resurrected Lazarus. His personal death and resurrection is a crowning symbol of his victory over the cosmic powers, which communicates his power very well, but it doesn't actually accomplish anything distinctive. It is one piece of a spectrum of actions that combat the powers. ${ }^{11}$ So, the theory leaves our question unanswered-it falls into the first pitfall. But the most widespread example of early Christus Victor theories-the Ransom Theory ${ }^{12}$ has an answer. By sinning, we fell under the power of Satan, who rightly subjects us to death. God cannot justly pull us directly from Satan's power. So, God offers Jesus as bait-as a human he is subject to death, but in his divine perfection he does not deserve death. Satan kills him, not seeing the hidden hook of divine perfection, thus

\footnotetext{
11 Boyd himself gives away the game when he admits, in a footnote, that "this account leaves unanswered a number of questions we might like answered. E.g., precisely how did Calvary and the resurrection defeat the powers?" $(2006,37)$ That's a big concession. Part of the goal of having a theory of atonement is to answer this question.

12 This theory is present in the Latin (Augustine, On the Trinity, bk. IV, XIII), Greek (Gregory of Nyssa, An Address on Religious Instruction), and Syriac (Narsai, "Homily for the Great Sunday of the Resurrection") church fathers.
} 
overstepping his just power. His punishment is that he loses the power of death over all other sinful humans. This story explains how Jesus's death contributes something distinctive to atonement: it is needed to justly release us from Satan's power of death. No other aspect of Jesus's ministry does this. Unfortunately, the Ransom Theory imports the problematic assumption that Satan has some rights against God. Anselm forcefully presented this and other objections ${ }^{13}$ and today it is rarely held. So, enriching the Christus Victor theory in this way runs right into the second pitfall.

Other objective theories face the same dilemma. Penal substitution theories offer a clear explanation for how Jesus's death atones-his death constitutes the punishment that guilty humans owed for having sinned against God. Jesus accepts the punishment due to us in our place. This explanation depends upon the highly questionable assumption that it is just for one person, innocent of wrongdoing, to suffer the punishment due to another for the latter's wrongdoing. ${ }^{14}$ Satisfaction theories tend towards ${ }^{15}$ not clearly explaining how Jesus's death atones in a way that respects (A3). Richard Swinburne's theory is a good example of this. On his view, atonement involves repentance, apology, reparation, and penance, where penance is conceived of as something given to or done for the victim that goes beyond mere compensation and is aimed at more richly expressing that the wrongdoer has disowned his wrong act $(1989,81-2)$. Sinful humans ought to offer all four of these things as atonement, but they are unable to offer adequate reparation and penance. Jesus offers reparation and penance for humans by living a life of perfect obedience to God - the kind of life humans should have lived. His death is part of this life of perfect obedience because the character of his life led unjust men to kill him (1989, 152-4). But on this view Jesus's death doesn't contribute anything distinctive to atonement. His death is simply one aspect of a life of obedience. Indeed, it is easy to imagine a way for Jesus to live a perfect life of obedience without submitting to crucifixion. ${ }^{16}$

My goal in this section has been to show that potential answers to our main question-how does Jesus's death atone for human sin?-face a difficult challenge: explain how Jesus's death contributes something distinctively important to atonement without importing seriously problematic assumptions. In the rest of this paper I shall try to meet this challenge. I will develop an answer to our main question that is based on uncontroversial principles of atonement that, when supplemented with a careful reflection on Old Testament sacrifices, explains how Jesus's death is distinctively important to his atonement. The answer that I give is a sort of

13 "Why God Became Man" bk. I, ch.7.

14 This objection-the Justice Worry-has been pressed by many. Anselm himself put forward a somewhat broader version of the worry $(1998,275)$. Socinus (Grensted 1920, 284-5) pressed it, along with several other objections. Today the objection is commonplace in the literature. See, for example, Lewis (2000) and Martin (1991, 252-63). In a sympathetic discussion of the penal substitution theory, Crisp (2008) nevertheless takes the Justice Worry to be decisive. Thurow (2015) argues that a communal version of the penal substitutionary theory can avoid this objection.

${ }^{15}$ Anselm's theory, however, gives a clear explanation. Although I don't have the space to argue the point here, I believe that his theory falls prey to the other horn by importing some questionable assumptions.

${ }^{16}$ See Porter (2004) for a very similar objection to Swinburne's theory. I believe Stump's (2003) Thomistic theory faces the same sort of worry. 
satisfaction view. Let's work up to it piece by piece, starting with the principles of atonement.

\section{Principles of Atonement}

My explanation of how Jesus's death is distinctively important to his atonement draws on six principles of atonement: five main principles and a corollary.

PA1. Atonement aims at reconciliation.

PA2. Adequate atonement should address both past wrongs as well as future character and behavior.

PA3. At least three kinds of acts contribute to atoning: A) communicating one's dissociation from the wrong action, B) improving morally, C) offering satisfaction, by which I mean acts aimed at either repairing the effects of one's wrong action or "making up for" what one did.

PA4. The victim has the power to determine (perhaps within certain limits) whether the wrongdoer's atoning attempts constitute adequate atonement.

PA5. The fittingness and adequacy of the manner of performing atonement depends on context.

One thing to keep in mind about these principles is that they do not constitute a theory of atonement in general, or of the Christian doctrine of atonement. They are merely five plausible principles about atonement. Different theories of atonement could be built around these principles.

These principles are each highly plausible. (PA1) follows directly from the notion of atonement as defined at the beginning of this paper. The diverse range of references cited in footnote 2 each support (PA1). Furthermore, the word "atonement" means "at-one-ment"; built right into its structure is the notion of being "at-one." When parties have been divided by some wrong, and then overcome that wrong and become "at-one" with each other, they have achieved reconciliation.

A corollary of (PA1) will play an important role in our discussion. In order to achieve the goal of atonement-reconciliation - the victim must in some way signal that the wrongdoer's acts of atonement have been accepted. Reconciliation cannot be achieved without the victim both accepting and communicating acceptance of the acts of atonement. The corollary, then, is:

C-PA1. In order for atonement to be successful, the victim must in some way signal acceptance of the acts of atonement.

(PA2) is intuitively plausible, especially in light of (PA1). If the goal of atonement is reconciliation, then the wrongdoer will have to do something to address the way he has wronged the victim. The wrong done is the source of division between the parties, so must be addressed to achieve reconciliation. (PA3) describes some ways the wrong can be addressed. The wrongdoer must also give the victim some 
reason to think that he has worked at changing his character and/or that he sincerely intends to behave differently in the future because the victim will rightly feel that the wrongdoer may attempt to victimize her again. Reconciliation would not be possible if the wrongdoer did nothing to address his future behavior. Both secular (Radzik 2009, 85) and religious (Stump 2003, 430, 454 and Stump 2012, 131-2) discussions of atonement have drawn attention to (PA2).

Once (PA3) is understood properly, it also is highly plausible. (PA3) implies that the three types of action, A, B, and C, contribute to atonement, but it does not imply that they are the only kinds of acts that can contribute to atonement. Submitting to punishment, for example, may also contribute to atonement. In addition, (PA3) does not imply that any of the acts of type A, B, and C is required for full and proper atonement. Some cases of wrongdoing (e.g., certain minor or accidental faults), may be atoned-for without either reparation or any acts of moral improvement beyond sincere apology. With these clarifications in place, (PA3) is evident. Communicating separation from the wrong action, working towards moral improvement, and offering satisfaction are all ways that a wrongdoer can either address the wrong done or attempt to modify his character and future behavior. ${ }^{17}$ It is easy to think of cases where these three types of actions contribute to atoning for wrongdoing.

Richard Swinburne elegantly states (PA4): "One consequence of my harming you is just that it is in part up to you whether my guilt is remitted.... The victim has the right, within limits, to judge when the wrongdoer's atonement suffices" $(1989,87$ 8). He argues that this is true because if instead one could remit one's guilt simply by meeting some objective standard of atonement, then one could wrong another and remove one's guilt at will. "That would not take seriously the fact that the act is an act by which you are wronged, and in the wiping out of which you ought therefore to have a say" $(1989,87)$. It would treat the victim as an agent entirely under one's own power, as a tool for one's own goals who needs to be paid off in some cases. This is a disrespectful way to treat one's victim. As Radzik argues, "an important way for the atoning wrongdoer to reestablish respect for the victim ... is to give the victim a say in what comes next" $(2009,123) .{ }^{18}$ Both Radzik and Swinburne believe that the victim does not have the ability to completely determine what suffices for atonement. There are some ethical limits. I agree, but I will not make use of this claim in what follows. Swinburne and Radzik have both given good reasons to believe (PA4). The fact that they both endorse this view from very different perspectives (Radzik from a secular perspective, Swinburne from a Christian perspective) further indicates that (PA4) is both plausible and non-controversial.

(PA5) - the fittingness and adequacy of the manner of performing atonement depends on context-fits very well with both (PA1) and (PA4). If atonement aims at reconciliation and victims have some power to determine whether an act of atonement is adequate, then what counts as a fitting and adequate act of atonement will depend upon contextual factors such as the history of the relationship between the offender and victim, the nature of the offense, how the victim feels most hurt by

\footnotetext{
${ }^{17}$ Radzik (2009: 85) discusses how these three types of action work to achieve reconciliation.

${ }^{18}$ Radzik (2009: 122) adds another reason based on the victim's special knowledge of how damage to her would best be repaired.
} 
the act, and cultural influences on the communicative content of various actions. As Radzik writes, "what we must do to restore our moral relationships with other people or ourselves will depend on the previous nature of those relationships, on the amount of strain that was placed on the relationships by the wrong, and on the legitimate expectations of the victims and the community" $(2009,106)$. Later on I shall draw special attention to how the communicative content of rituals can make them particularly fitting as acts of atonement.

\section{Sacrificial Atonement in the Old Testament}

Early Christians regarded Jesus's death as an atoning sacrifice for sin (Mt 26:28; Rom 3:25, 5: 8-11; 1Cor 15:3; Eph 1:7, 5:1; Col 1:20-2; Heb 2:17, 9:11-22; 1Pet 1:18-9; 1Jn 1:7, 2:2, 4:10). ${ }^{19}$ Plainly the early Christians are drawing on their experience of certain Jewish purificatory and expiatory sacrifices, especially the Day of Atonement ritual. Although early Christians thought the Jewish sacrifices were inadequate for atoning for human sins-Jesus's actions were needed-the fact that they understood Jesus's work as a sort of Jewish atoning sacrifice indicates that, on the Christian view, Jesus's work does whatever it is that those sacrifices aimed at and were fit to do by way of atonement, however inadequately. ${ }^{20}$ So I suggest that understanding how these sacrifices are fit to atone, regardless of their adequacy, will help us to understand how Jesus's death distinctively contributes to atonement.

To understand how sacrificing an animal may be a fitting act of atonement in the Jewish context we need to see how the sacrificial act fits within the broader sacrificial process of preparation, offering, and subsequent manipulation of the sacrifice. We shall see both that each aspect of this process contributes to atonement and that features of the broader process explain why the death of the sacrifice plays a distinctive role in atoning for sin.

Our goal in discussing the broader sacrificial process will thus be to answer the following questions: Q1) how is the Jewish expiatory sacrificial process a fitting (though perhaps not ultimately adequate) means of atonement for sin? Q2) what distinct role does the death of the offering play in atonement?

\subsection{The Sacrificial Process}

The main function of sacrifice-both expiatory and non-expiatory-was to attract and maintain the divine presence among Israel in the sanctuary (Klawans 2006, 6872). God's presence would in some sense reside amongst the Israelites, guiding them and protecting them from hostile forces. Moral and ritual transgressions can defile the sanctuary with impurity (Klawans 2006, 53-6). If impurities reach a critical level, God's presence might abandon the sanctuary (Milgrom 1991, 258-61). Expiatory

\footnotetext{
${ }^{19}$ For patristic references, see Turner 1952, 96-113. Other sacrificial notions are also used to describe Jesus's work, including those of covenant sacrifice (Mk 14:24) and Passover sacrifice (Jn 1:29, e.g.).

20 This is consistent with the common Christian idea that the Jewish sacrifices were figures or images of Jesus's atoning sacrifice.
} 
sacrifices aim to maintain God's presence by removing moral impurities that have tarnished the sanctuary. Such sacrifices are accurately called both purification sacrifices (because of their purificatory effect on the sanctuary) and sacrifices of atonement (because of their ultimate aim at reconciling a tension between the Israelites and God due to Israel's sin, resulting in God continuing to live with the Israelites).

Sacrifices, then, are gifts to God aimed at initiating and maintaining a favorable relationship with God. ${ }^{21}$ These sacrifices are accepted only if they are prepared, offered, and manipulated appropriately. Each of these three parts of the sacrificial process thus contribute to offering fitting atonement. Animal sacrifices were fitting means of atonement because (i) the preparation for offering a sacrifice repaired and counteracted the harmful effects of sin, (ii) the offering represents that the offerer should have been morally pure, and (iii) the symbolic content of the blood of the sacrifice enables it, when manipulated properly, to communicate the removal of guilt and its effects.

Concerning (i): Jonathan Klawans $(2006,56-66)$ has forcefully argued that the person offering a sacrifice imitates God in various ways. He must be ritually pure, which involves dissociating himself from things that lead to or represent death, such as ritual impurity. God himself cannot die and thus through ritual purity the sacrificer imitates God. The sacrificer must also select an unblemished animal. To do so, the sacrificer must imitate God in being a shepherd who raises his flock, tending it carefully so as to produce unblemished animals. God is himself described as a shepherd that tends his flock. The Israelites were called to imitate God-they were to be holy as the Lord their God is holy (Lev. 11:44-5, 19:2, 20:7, 26). To imitate God is also to restore the image of God in humanity, which the narrative of Genesis indicates had become somewhat tarnished. So, by imitating God in preparation for making the sacrificial act, the sacrificer is repairing the harmful effects of sin by being what he should have been-one who imitates the holiness of God. Of course, God is not himself harmed by sinful deeds, but things he cares about-humans, their relationship to him, the community of Israel-are damaged by sin. The sacrificial system-through the effects of preparing the offering of sacrifices-repairs the damage sin does to these things that God cares about.

Concerning (ii): Since the sacrificer plays the role of God in raising and choosing the sacrificial offering, the offering plays the role of the human. Only an unblemished animal will serve as an adequate sacrifice. The unblemished animal thus represents a pure human. So, the sacrificial offering itself represents what the human offerer should have been-morally pure and submissive to God. The sacrificer will have noticed what his offering represents, and so to offer it at the Temple is a visual, active way of both confessing to God that he should have been holy and obedient, and repenting of his sinful ways. Confession and repentance are components of atonement for serious wrongdoing, and the more serious the wrongdoing the less a mere verbal declaration of confession and repentance is adequate. The sacrificial offering is a good example of a serious, public enactment of confession and repentance, which seems appropriate for serious wrongs.

${ }^{21}$ Halbertal (2012, 14-15); Milgrom (1991, 441). 
Concerning (iii): We have just seen how the sacrificial offering is an act of communication from the sacrificer to God. The actual sacrificing of the animal and subsequent manipulation of it is also an act of communication from God to the sacrificer. Since God authorized the sacrificial system and chose a group of priests to carry out this system, priests communicate on behalf of God through their ritual, divinely authorized, acts. So by the priest slaughtering the animal and sprinkling the blood on parts of the Temple, God communicates that he has accepted the offering and that the impurity cast on the temple by the sin has been removed. God thus communicates that the sinner's guilt is removed and that the sinner's sin will not contribute to driving God away from the community. God can communicate this message because, as Jacob Milgrom (1991, 45-7) has argued, the blood of the animal represents life, whereas the impurities on the Temple due to sin symbolize deathseparation from God, and literal death and decay, both of which will occur if God is driven from his sanctuary. The rubbing and sprinkling of blood-indeed, blood from a spotless victim that represents holiness-thus symbolizes holy life washing away death, and so the death that results from a wrongdoer's sin is removed by the life of the offering. We needn't assume that blood has an intrinsic power to dissolve impurity. We need only assume that because of what it represents and how it is offered, God accepts it as an adequate atonement, allowing it to dissolve the impurities. ${ }^{22}$

It is crucial that God communicates his acceptance of the sacrifice through the sacrificial process. We noted above (C-PA1): in order for attempts at atonement to be successful, the victim must in some way signal acceptance of the acts of atonement. Both God and humans desire successful atonement, but that can't happen if the sinner doesn't know that God accepts his offering. Since God is immaterial, humans can't just read God's face or mannerisms to determine whether he accepts their offerings. And God typically doesn't literally vocalize himself to humans. So, there needs to be some other means of communicating God's acceptance to humans. The sacrificial process includes God's communication of acceptance through the symbolic content of wiping/sprinkling blood by his authorized priests.

Why must the offering die? Couldn't (i), (ii), and (iii) all obtain while simply bleeding the animal a bit, but not killing it? There are two, possibly three reasons why it is important that the animal die. First, the offering is a gift to God; if the animal survives and is then acquired by either the priests or the offerer the gift hasn't been given; it has been taken back or given to someone else. Killing and burning the offering removes the animal from the realm of human possession, thus enabling it to function as a gift to God. Second, the gift is to be the life of the animal, for use in purification of the sanctuary. If the animal survives, its life hasn't been given. The blood of the animal represents and carries its life. If the animal's life is going to purify, its life needs to be given, which requires its death. Thus the blood of the animal symbolically represents holy life, thereby acquiring purificatory power only if it is slain. Third, many have argued that since the animal offering represents the giver, its

22 We can remain neutral about the metaphysical nature of impurity. Perhaps impurity is some sort of nonphysical objective state, or perhaps there is nothing more to impurity than divine unease with Israel. 
death represents a punishment of the giver. Halbertal observes that the rabbi Rashi claimed "blood as a representation of life can serve as a ransom - that is, as a symbolic substitute for the sacrificer's life" $(2012,30)$. This interpretation of the sacrifices is disputed, but arguably this symbolic resonance is present in early Christian interpretations of Jesus's death. We shall return to this point later.

\subsection{Answering Q1 and Q2}

We are now in a position to answer our two questions. First, Q1: how is the Jewish expiatory sacrificial process a fitting (though perhaps not ultimately adequate) means of atonement for sin? It is fitting in virtue of the following three features:

(SOFi) the preparation of the sacrifice repairs the damage of sin to some extent,

(SOFii) the offering represents that the offerer should have been holy and obedient, thus constituting public confession and repentance, and

(SOFiii) the symbolic content of the blood of the sacrifice enables it to communicate, through wiping/sprinkling, that God has accepted the act of atonement and so has reconciled himself to the offerer.

These features explain why God might accept these offerings as fitting means of atonement. The reparation, confession, and repentance involved in (SOFi) and (SOFii) (which are also thus attempts at moral improvement) fit well with (PA2) and (PA3).

Because of (SOFiii) the sacrifices also enable God to communicate acceptance of the sacrifice, thus fitting well with (C-PA1). These sacrifices integrally entwine the human act of atonement together with divine acceptance of that act, thus achieving reconciliation with God, which according to (PA1) is a goal of atonement. All along, the authority of God to determine what counts as an adequate atonement is assumed since God himself set up the sacrificial means of atonement, God's priests act on his behalf to carry out the sacrificial rituals, and God can sometimes reject the sacrifices. ${ }^{23}$ Thus (PA4) is acknowledged.

Now on to Q2: what distinct role does the death of the offering play in atonement? Death enables the blood of the pure sacrifice to symbolically represent life covering and washing away death due to sin. So the offering's death enables its blood to communicate in the way that (SOFiii) requires. Furthermore, God accepts the sacrifice as atonement in virtue of the fact that the blood of the sacrifice represents what it does (provided the sacrifice is also offered and manipulated appropriately). So the offering's symbolic content itself is an explanation for why the offering atones. In addition, its death may also represent punishment due to the offerer, which the offerer will recognize and thus the offering of it will constitute an admission that the offerer merits punishment. This will deepen the confession and repentance involved in offering up the sacrifice.

${ }^{23}$ See 1Sam 15:22-3; Isa 1:11; Jer 6:20; Hos 6:6; Amos 5:21-4; Micah 6:6-8; Psalm 40:6. 
Because of how well the expiatory animal sacrifices fit with the principles of atonement, they are surely at least a fitting, if not adequate, means of atonement for human sin. Why not adequate? Perhaps for two reasons. First, the reparations offered are low for some of the sins that are committed-in particular, human victims should perhaps receive more reparation-and second, the offerings are weak efforts at moral improvement, as evidenced by (according to the OT narrative) the fact that they didn't seem to actually produce much in the way of moral improvement. ${ }^{24}$ The first worry is mitigated at least somewhat by the fact that several of the Jewish sacrifices, such as the offerings for sacrilege against sancta (Lev. 5:14-16) and for sacrilege against oaths (Lev. 6:1-7) also required that the sinner offer some sort of reparation to affected human parties. The second worry is a bit more challenging. Perhaps the minimum bar for moral improvement through atonement is pretty low. We often accept apologies from those who have hurt us in various ways even though we have little grounds (and we know it) for thinking that they will actually be better in the future. Their apology gives us reason to think they will try to be better, and that is often enough for us. Perhaps God also uses such lenient standards. Even so, one might (as Christians do) still have a residual sense that these sacrifices aren't quite adequate. In the next section we will see how the understanding of sacrificial offerings developed here can be used to explain how Jesus's death is an adequate atonement.

\section{How Jesus's Death Atones}

Now we are ready to face the central question of the paper: how does Jesus's death atone for human sin? Drawing on the New Testament idea that Jesus's death is an atoning sacrifice for sin, we can take the above understanding of the Jewish atoning sacrifices and substitute Jesus's death for the death of the animal. Just as the whole Jewish sacrificial process of preparation, offering, and manipulation contribute to atonement, so various aspects of Jesus's life that amount to preparation, offering, and manipulation of his sacrifice of himself will contribute to atonement. Just as the death of the animal sacrifice plays a distinctive role in this broader sacrificial process, so Jesus's death plays a distinctive role in the aspects of his life that together comprise the broader sacrificial process. Jesus's atoning work has parallels to each of the three features of the Jewish atoning sacrificial process discussed above. In this section we will explain these parallels and then answer two questions (parallel to Q1 and Q2 about the Jewish sacrifices): Q3: how is the broader process surrounding Jesus's sacrifice-the preparation, offering, and manipulation of it-a fitting means of atonement for sin, and Q4: what distinctive role does Jesus's death play in atonement? The answers to these two questions will together explain how Jesus's death atones for human sin.

${ }^{24}$ The Letter to the Hebrews seems to level exactly this charge against the Jewish expiatory sacrifices when it says that those sacrifices could never "make perfect those who approach" (Heb 10:1-4). See also Heb 7:11-12, 10:14. 


\subsection{Parallels between Jesus's Sacrifice and the Jewish Sacrifices}

Just as the process of preparing and presenting the Jewish expiatory sacrifices repairs the damage of sin to some extent (SOFi), so the process of preparing and presenting himself for crucifixion repairs sin to some extent. Since according to Christians Jesus was sinless, he isn't repairing the damage of his own sin. Rather, he repairs the damage of the sin of humanity. He does this in many ways-through teaching, healing, acts of love and mercy, calling together a band of followers to spread his message, and bravely enduring opposition. Much more could be said to elaborate on this point, but in short Jesus worked to guide the course of humanity in a more holy direction. (This aspect of his ministry continues on after his resurrection, a point to which we will later return.) Furthermore, early Christians regarded his sinlessness as part of what made him a fitting sacrifice (and fitting to offer himself as a sacrifice). ${ }^{25}$ So his whole life of service to God functions analogous to the preparation of an offering to ensure the offering is pure.

Just as Jewish expiatory offerings represent that the offerer should have been holy and obedient (SOFii), so Jesus's offering of himself represents that humanity should have been holy and obedient. Jesus offers himself as an atonement for human sin as a whole. His offering of himself thus more closely resembles the Day of Atonement offering - which is given once per year for the sins of Israel as a wholethan the sacrifices individuals offer for their personal sins. The high priest's offering represented what Israel should have been like and thus can play an integral role in confession and repentance. There are at least two ways to understand this role: a) the high priest's offering constitutes a corporate confession and repentance for Israel, or b) the high priest's sacrifice is offered on behalf of every individual Israelite that observes the Day of Atonement and thus the sacrifice partially constitutes each observant Israelite's own personal confession and repentance. Similarly, Jesus's offering of himself represents what humanity should have been like and so can play an integral role in confession and repentance. ${ }^{26}$ Notice further that Jesus represents that humanity should have been holy and obedient in a far richer way than the Jewish expiatory sacrifices-he actually embodies holiness and obedience in a human life, whereas the other sacrifices merely symbolically represent holiness and obedience.

The preceding two points at least begin to explain how Christians might regard Jesus's sacrifice as more adequate than the Jewish expiatory sacrifices. Jesus's preparation for his sacrifice did a lot more to heal the effects of sin than did human

\footnotetext{
25 See, for example, Heb 5:8-10; Heb 7:26-28. Rutledge observes that "the life of Jesus is singlemindedly directed toward his self-offering," and then she quotes John Donne, "All his life was a continual passion"' $(2015,31)$.

${ }^{26}$ On the (a)-understanding, Jesus's sacrifice constitutes confession and repentance for humanity as a whole; on the (b)-understanding, his sacrifice constitutes part of the confession and repentance of followers of Jesus who accept his sacrifice as being offered for them. Vicarious penitence theories of atonement, such as John McLeod Campbell's focus on this aspect of Jesus's sacrifice in explaining the atonement (Purves 2015, 109-117).
} 
offerings of the other sacrifices. ${ }^{27}$ Furthermore, Jesus better and more fully represented what humans should be like than did the other sacrifices.

The third key feature (SOFiii) of Jewish expiatory sacrifices is that the symbolic content of the blood of the sacrifice enables it to communicate, through wiping/sprinkling, that God has accepted the act of atonement and so has reconciled himself to the offerer. Because it represents washing away death and the impurities of sin with life (which enables God to communicate back to humans that sin has been forgiven), God accepts the blood of the sacrifice as fitting atonement. Early Christians place similar significance on Jesus's blood. A statement from Colossians is typical: "through him [i.e., Jesus] God was pleased to reconcile himself to all things ... by making peace through the blood of his cross" (Col 1:20). ${ }^{28}$ Once Jesus's death is thought of as a sacrifice, it is very easy to regard his blood-just like the blood of the Jewish expiatory sacrifices-as being a sign of purity, holiness, and life that God accepts as a means for wiping away sin. In virtue of the parallels with SOFi and SOFii, Jesus doesn't just represent, but embodies, moral purity and obedience. And in virtue of the Jewish view of the symbolic content of pure sacrifices, Jesus's blood, offered through his death, can represent life that washes away death and the impurities of $\sin$.

But how would one know that God accepts the blood of a death like this if the blood isn't wiped and sprinkled in the normal way? The answer is a novel but apt expansion on the symbolism of (SOFiii): resurrection. By raising Jesus from the dead God communicates that he accepts this sacrifice and that the blood of this sacrifice will wipe away sin. Resurrection is a particularly effective way to communicate acceptance. The blood of a sacrifice symbolizes pure and holy life that covers over sin and so brings about further life for the individual and for the community in God's presence. By raising Jesus from the dead God thus vividly communicates that this sacrifice will bring about further life in God's presence-Jesus himself received his life again in a more glorified state. Since Jesus is God incarnate, his resurrection communicates that God himself will remain with humanity, despite their sin, for eternity. Jesus's resurrected life also shows us what life fully reconciled with God will be like, and so by resurrecting Jesus he communicates that Jesus's sacrifice atones for sin, enabling those who follow him to eventually obtain such a life for themselves. The resurrection, then, is an integral part of Jesus's atoning act. ${ }^{29}$

\footnotetext{
${ }^{27}$ Hebrews 10:1-2 complains that the OT sacrifices cannot make humans perfect. In contrast, the author proclaims that "by a single offering he [i.e., Jesus] has perfected for all time those who are sanctified" (10: 14).

${ }^{28}$ The italics are mine. For other examples, see most of the passages listed above at the beginning of the first paragraph of section three.

${ }^{29}$ Paul writes, "If Christ has not been raised, your faith is futile and you are still in your sins" (1Cor 15:17). In his recent study of the book of Hebrews, David Moffitt (2013) argues that the author of Hebrews develops a further connection between Jesus's death and atonement: Jesus must be resurrected so that he can function as a high priest of a new covenant and, as high priest, he presents his resurrected body in the heavenly holy of holies as the atoning sacrifice for humanity. Presentation of his resurrected body is a way of presenting the blood of his sacrifice in the heavenly temple to wipe away sin once and for all. Moffitt's argument is consistent with my explanation, but is not necessary for it.
} 


\subsection{Answering Q3 and Q4}

We are now in a position to answer our two main questions. First, Q3: how is the broader process surrounding Jesus's sacrifice-the preparation, offering, and manipulation of it - a fitting means of atonement for sin? It is fitting in virtue of the following three features:

(JAi) his life, led in preparation for his death, was a substantial reparation for human sin,

(JAii) his moral perfection and holiness richly represents how humanity should have been, thus enabling humanity to richly confess and repent to God by offering a representation of what they should have been, and

(JAiii) the symbolic content of the blood shed at Jesus's death enables God to communicate to humans that he accepts Jesus's death as an act of atonement. Jesus's resurrection communicates acceptance of the sacrifice and furthermore enables God to communicate more vividly that imitating the life of Jesus - which was offered as a representation of how humanity should have lived-will lead to a reconciliation with God and life in his presence forever. This is something God couldn't do with the animal sacrifices.

Now on to Q4: what distinctive role does Jesus's death play in atonement? (JAiii) contains the answer. Jesus's death enables the blood of his pure sacrifice to symbolically represent life covering and washing away death due to sin. Jesus's sacrifice is a pure offering because of the things mentioned in (JAi) and (JAii)-he lived a morally perfect life that offered substantial reparation for human sin. The death of this pure sacrifice thus enables Jesus's blood to communicate in the way that (JAiii) requires. Furthermore, God accepts Jesus's sacrifice as atonement in virtue of the fact that the blood of his sacrifice represents what it does; the symbolic content of Jesus's offering of himself as a sacrifice itself is an explanation for why his selfoffering atones. Notice that it is against the backdrop of Jewish expiatory sacrifices that Jesus's blood can communicate what it does. The fifth principle of atonement, (PA5), states that the appropriateness and fittingness of the manner of performing atonement depends on context. As we've seen, in the Jewish context sins were atoned for through pure sacrificial offerings whose blood was used as a means of communicating that sin had been wiped away. ${ }^{30}$ In this context the blood of something pure has communicative power, which is what enables Jesus's death to serve as a means of atonement. Indeed, given the Jewish backdrop, it is hard to see how God could have communicated acceptance of an atoning act for all human sin

Clearly it wouldn't be enough for Jesus to simply declare that his death would take away sin, without the resurrection. For then there wouldn't be a visible sign communicating that sin and death had been wiped away-no blood sprinkling to wash away sin, no resurrection to show new life. In addition, there would be serious grounds to question whether Jesus was correct, and so serious reason to question whether reconciliation has occurred. Thus it would be at best unclear whether CPA-1 was satisfied.

${ }^{30}$ Hengel (1981) argues that it wasn't only in the Jewish context that sacrificial offerings had this communicative power. 
that didn't involve the blood of a pure sacrifice. ${ }^{31}$ Since there was an established means of atoning for human sin-by way of sacrifice-any other non-sacrificial means would have left a question as to whether adequate atonement had truly been given. So, given the Jewish context, (PA5) enables us to explain both why Jesus's death contributes something distinctive to his atoning work and why (if not necessary) it is at least extremely fitting that Jesus's atoning work include his sacrificial death. ${ }^{32}$

Why death rather than just bleeding Jesus without death? Three answers can be given, exactly parallel to the three answers given above to the same question for the Jewish sacrifices. I'll focus here on two of them. First, in order for his blood to represent his life, his life has to be given. Blood in any other circumstance not involving death would not represent the life of a pure sacrifice.

The second will help us answer a more specific question about his death: why did he die the way he did-why crucifixion? Colossians 1:20 states that "through him [i.e., Jesus] God was pleased to reconcile himself to all things ... by making peace through the blood of his cross." This may be taken to suggest that his being crucified, not just his dying, contributes something distinctively important to atonement. What might that be? The idea (mentioned earlier) that Jewish sacrifices represented punishment due to the sin of the offerer can help answer this question. Fleming Rutledge argues that "no other mode of execution would have been commensurate with the extremity of humanity's condition under Sin" $(2015,102)$. The idea is that by submitting to crucifixion Jesus expresses humanity's sinful plight; crucifixion is a death for a criminal, rebel, and a slave (Hengel 1977). Humanity is a criminal in violation of God's law, an idolatrous rebel, and a slave to sin. Paul makes this connection in Galatians 3:10-14 using passages from Deuteronomy which say that everyone who does not follow the law of God is cursed (Deut. 27:26) and that anyone that hangs on a tree for a crime punishable by death is cursed (Deut. 21:23). As a representative offering atonement for humanity, through submitting to crucifixionhanging on a tree-Jesus can express that humanity is guilty of grave sins and crimes. ${ }^{33}$ (PA2) and (PA3) explain why it is fitting that an act of atonement express

\footnotetext{
${ }^{31}$ Heb. 9:22 says, "Indeed, under the law almost everything is purified with blood, and without the shedding of blood there is no forgiveness of sins."

32 One might object that in the Jewish tradition, only an animal sacrifice can atone and human sacrifice is forbidden, so Jesus's death can't be understood as an atoning sacrifice. However, the Jewish tradition contains various suggestions that human suffering and death can atone for sin as a sacrificial offering. Is 53 contains the famous suffering servant passages, which say of that servant that "he was pierced for our transgressions, and he was punished for our iniquities...the Lord has laid on him the iniquity of us all" and "the Lord makes his life a guilt offering" (v.5, 6, and 10). The deuterocanonical book 4 Maccabees (a product of second Temple Judaism, likely written around the time of Jesus) envisions the Jewish martyrdoms under the rule of Antiochus Epiphanes as "a ransom for the sin of our nation....and their death as an atoning sacrifice" (4Macc 17:21-22). Lastly, Jon Levenson (1993, 173-199) argues that various figures in early rabbinic Judaism, perhaps drawing on exegetical moves that originate much earlier, thought of Isaac's near-sacrifice at the hands of Abraham as a foundational event that explains why God accepts animal sacrifices at the Temple (which some thought was built at the site of Isaac's near-sacrifice). Some even spoke of the blood of Isaac as meriting expiation of the sins of Israel. 33 Defenders of vicarious penitence, such as John McLeod Campbell, would find this move quite congenial (see Purves 2015, 109-114).
} 
the true nature of the faults to be atoned for because doing so is a way of addressing past wrongs and also part of dissociating from those wrongs.

The principles of atonement can thus be used to explain why Jesus's atoning act contains a stark juxtaposition: while Jesus hangs on the cross he himself represents what humanity should have been while his hanging on the cross represents what humanity in fact has been.

I've explained how Jesus's death is distinctively important to his atoning work, and I've also offered at least a partial explanation of why his atoning work, including his death and resurrection, are (from a Christian perspective) more adequate acts of atonement than the Jewish expiatory sacrifices. We can build up the latter explanation with one more point. One of the results of Jesus's death, according to Christians, is that he later sends his Holy Spirit to dwell in and guide his followers. On the Christian view the Holy Spirit acts to guide Christians and help them to more adequately follow God's will. If we include this effect of his death as part of his atoning work, then his entire atoning work contains an everlasting mechanism for continuing to repair the damage of $\sin$ in humanity. That would seem to greatly increase the adequacy of Christ's atoning work. ${ }^{34}$

\section{Situating the Explanation and Two Questions}

This explanation of Jesus's atoning work-both of the work done throughout the preparation, offering, and subsequent manipulation of his sacrifice of himself and, more specifically, of the atoning significance of his death-is an objective theory of atonement. The many things Jesus did throughout his life that made him a pure sacrifice objectively atoned through offering reparation. His death objectively enables his blood to symbolically represent life washing away death due to sin, thus objectively enabling God to communicate his acceptance of Jesus's atoning work. Jesus's death thus isn't merely a subjective factor in atonement because it doesn't merely incite or encourage a response of some sort from followers whose sin is being atoned for.

It is valuable to contrast the objective explanation I've given of the atoning significance of Jesus's death with other prominent explanations. First, my explanation does not assume that God "demands" a price of blood as satisfaction for sin. Rather, Jesus's death is part of a distinctively fitting way for humanity to offer reparation for sin while also allowing God to communicate acceptance of the act of atonement. Second, my explanation does not assume that God's honor is offended and that something must be done to restore God's honor. Rather, all that is assumed is that sin

\footnotetext{
${ }^{34}$ My proposed explanation of how Jesus's death distinctively contributes to atoning for human sin explains why the apostles seemed to recognize Jesus's death as a sacrifice only after his resurrection. The ritual slaughter of an animal only counts as a sacrifice when it is performed and the remains handled in a way that is authorized by God. Seeing the resurrected Jesus enabled the apostles to think of Jesus's death as somehow authorized by God for the salvation of humanity. Then they were able to reinterpret the events of Jesus's life as a sacrifice and to see that certain of Jesus's purported sayings perhaps indicated that Jesus himself saw this as his mission all along. Before seeing God's authorization, it would be hard to see Jesus's death as anything more than a tragedy.
} 
wrongs God and creates a rift between humans and God. Third, my explanation does not assume that Jesus's death constitutes a punishment for human sin. The manner of his death might symbolically represent punishment that is due to humanity, but Jesus is not punished for humanity and God does not demand that someone be punished for humanity's sins. Rather, by symbolically representing punishment due to humanity, his death enables humans to more deeply confess, repent, and acknowledge the depth of their sin. Fourth, my explanation does not assume that Jesus's atoning acts must have a sufficiently large positive value to outweigh the negative value of sins. No religio-hedonic calculus is needed. Plainly adequate atonement has to have some substantial positive value, but we needn't employ religio-hedonic accountants to figure out whether it puts our moral credit/debit balance sheet in the black. God has the power to decide whether an act of atonement is adequate. ${ }^{35}$

Although my explanation of how Jesus's death distinctly contributes to atonement for human sins is plainly an objective explanation, I do not assume that it is the only objective explanation. The explanation I've given may well turn out to be only part of the true, full explanation. Indeed, the explanation I gave in (JAiii) alluded to another way in which Jesus's death distinctively contributes to atonement: his death is a necessary part of his death and resurrection, and those two events together vividly communicate that imitating Jesus, who himself lived in service of God as humans all along should have lived, will lead to reconciliation with God and that even death will not stand in the way of life with him forever. Why should such a communicative act be part of the atoning act? Since the goal of atonement is reconciliation, and the Christian understanding of reconciliation involves bearing the untarnished image of God-that is, imitating God in the way we were designed to imitate him-it is quite fitting in light of (PA1), (PA5) and (C-PA1) that the act of atonement include some sort event that both embodies a restored human life that bears the image of God as it was meant to, while also communicating the way to obtain such a life. Jesus's resurrected life embodies such a life and his death and resurrection communicate divine assurance that following Jesus is the way to obtain such a lifeeverlasting, unstoppable by death, and fully reconciled with God.

I want to conclude by briefly discussing two questions facing the explanation I've given of how Jesus's death is a distinctively important part of his atoning act. The explanation, again, in short, is that because of the Jewish sacrificial background the blood of a pure victim (offered in the right sort of way with the right sort of intention) has the power to communicate the washing away of sins. Jesus's death atones because through it his blood acquires this communicative power. In the first-century context it would have been very hard to adequately communicate that the sin of humanity had been fully atoned-for once and for all without involving the blood of an innocent victim. This all raises the following question: why would God even start accepting animal sacrifices as means of atonement if this is going to lead to a system in which remission of sin could only be fully communicated through the death of an innocent human?

35 The second and fourth points indicate ways that the view I've defended differs from Anselm's satisfaction view. The third point distinguishes my view from penal substitutionary views. 
The first response is a dialectical point: this question faces all theories of atonement. Every theory of the Christian doctrine of the atonement is going to have to explain why God would, at least for a while, accept animal sacrifices as means of atonement. What is a challenging question for all theories provides no reason to favor one theory over any others. Of course, lacking an adequate answer to this question might lead one to argue that no theories of atonement are adequate and thus that the doctrine is simply false. I don't want to dismiss such an argument outright; it is certainly very much worth our attention, and so I will try to evade it by answering the question. But, should my answer be less than fully persuasive, it is nevertheless valuable to have a theory of atonement that explains how Jesus's death contributes something distinctively important to atonement without employing problematic assumptions that other theories of atonement have employed.

So, why might God even begin accepting sacrificial offerings as a means of atonement? This is a difficult question for which I can here only provide a partial, somewhat speculative answer. The answer is that animal sacrifices bring together and resolve two phenomena connected with resolving sin. The first phenomenon is that people seem to naturally experience their moral guilt resulting from wrongdoing as a sort of taint or stain. Stains need to be eliminated by a detergent of some sort. The second phenomenon is that one ought to atone for one's wrongs, which should involve addressing the past wrong and future behavior. So the act of atonement, especially for serious wrongs, should involve some sort of reparation and attempt at moral improvement. Animal sacrifices enable humans to offer reparation and work toward moral improvement, for as we noted above the process of preparing the offering involved imitation of God. In addition, serious wrongs are best resolved through costly means: the reparation will be costly, and the wrongdoer will have to show remorse and repentance through a more serious means than mere vocalization. Animals were quite valuable to ancient people; giving one up in reparation would thus be costly. A costly gift that also represents how the offerer should have behaved is one means of seriously communicating remorse and repentance. So, presenting the animal is a means of offering reparation, engaging in moral improvement, and showing repentance. Then, the offering itself provides the detergent-blood-to wipe away the felt stain of guilt. And the blood is a fitting detergent because of what it represents: the life of something pure (itself representing how the wrongdoer should have lived), which counters the death due to guilt. Expiatory animal sacrifices are widespread throughout ancient civilizations, which suggests that it is very easy for humans to see blood as a purifying detergent (when offered in the right way). God will see that humans will be able to make amends with God and feel their guilt resolved through a system of animal sacrifices. God may then choose to accept these sacrifices as sufficient for atonement (when done in the right way) because he loves humans and wants to give them a way to atone for their sins that they will understand and that will communicate to them that they have been reconciled with God.

The second question is this: has my account run right into the challenge for objective theories by importing a problematic assumption? In particular, my account assumes that it is wise or at least permissible to voluntarily sacrifice oneself as an innocent person in order to enable oneself to serve as a means of communicating acceptance of atonement. Is that assumption problematic? I don't think so. It would 
be problematic if one were forced to sacrifice oneself in order to play this role, but Jesus isn't forced to sacrifice himself. According to the Christianity he voluntarily accepts his role as a sacrifice (see Lk 22:42). It doesn't seem wrong to sacrifice oneself in order to make of oneself a symbol. Plenty of people have sacrificed their lives in the course of doing some good, recognizing that their sacrifice has mostly symbolic value-for example, caring for a very sick person who will likely die anyway knowing that one will likely contract the disease and die. Making that sort of sacrifice communicates the deep value of the sick person and people with similar ailments. It isn't wrong to sacrifice oneself in this way; indeed, to many of us it seems noble. Maybe this sort of sacrifice could be criticized as unwise if there are other ways of caring for sick people just as well that don't require sacrificing one's life. But there isn't clearly another equally good way of achieving atonement for human sin than through the death of a pure sacrifice given the Jewish context of sacrifice (as I argued in section 4.2). Furthermore, the whole broad process of Jesus's sacrifice offered more adequate atonement than the animal sacrificial process. It seems morally acceptable and wise to make a symbol of oneself in order to achieve something great-in this case, atonement for human sin and reconciliation with God-when there aren't, in the context, equally good ways of achieving the same goal.

The doctrine of the atonement is as challenging to understand as it is central to the Christian religion. I believe that I have succeeded in presenting an explanation of how Jesus's death distinctively contributes to atonement for human sin. The explanation given avoids controversial commitments of other theories of atonement and relies only on uncontroversial principles of atonement. It thus avoids the challenge raised in section 1 . When investigating particular doctrines, philosophers of religion and philosophical theologians investigate whether it is possible to understand them in a logically consistent way that avoids various theoretical and philosophical objections. What I have offered is such a piece of philosophy of religion or philosophical theology and, if my argument is correct, we have gone some way towards showing that there is such a way to understand the doctrine of the atonement. Whether the explanation I've proposed articulates the genuine Christian doctrine is another matter-one for systematic and biblical theologians. However, the way l've developed the explanation based on an interpretation of Jewish expiatory sacrifices and their use in the New Testament to explain Jesus's death may be grist for the systematic and biblical theological mill. Whether the explanation I've given is true is yet another matter-one that depends upon the truth of Christianity, for which I haven't even begun to argue. ${ }^{36}$

\footnotetext{
${ }^{36}$ Much of the research for this essay I conducted while on a fellowship at the Center for Philosophy of Religion at Notre Dame. Many thanks to all the people at the Center who make it an excellent place for philosophical research and discussion. Thanks to audiences at the Center and at the 2016 Midwest meeting of the Society of Christian Philosophers for feedback and discussion. Thanks especially to Carl Mosser, Michael Rea, Richard Swinburne, and anonymous referees for helpful comments.
} 


\section{References}

Anselm. 1998. Why God Became Man. In Anselm of Canterbury: The Major Works, ed. Brian Davies and Gillian Evans. Oxford University Press.

Athanasius. 1996. On the Incarnation. St Vladimir's Seminary Press.

Augustine. 2012. The Trinity, trans. Edmund Hill. New City Press.

Aulen, Gustav. 1931/1970. Christus Victor. An Historical Study of the Three Main Types of the Idea of the Atonement, trans. A.G. Hebert. SPCK Press.

Beilby, James and Eddy, Paul R. 2006, ed.'s, The Nature of the Atonement: Four Views. Intervarsity Press.

Crisp, Oliver. 2008. “The Logic of Penal Substitution Revisited." In The Atonement Debate, ed. Derek Tidball, David Hilborn, Justin Thacker. Zondervan.

Daly, Robert J. 2009. Sacrifice Unveiled. T\&T Clark.

Fiddes, Paul. 1989. Past Event and Present Salvation. Westminster/John Knox Press.

Forsyth, P.T. 1910/1938. The Work of Christ. Independent Press.

Gregory of Nyssa. 1954. "An Address on Religious Instruction." In Christology of the Later Fathers, ed. Edward Hardy. Westminster/John Knox Press.

Grensted, L.W. 1920. A Short History of the Doctrine of the Atonement. Manchester University Press.

Halbertal, Moshe. 2012. On Sacrifice. Princeton University Press.

Hengel, Martin. 1977. Crucifixion in The Cross of the Son of God. SCM. . 1981. The Atonement in The Cross of the Son of God. SCM.

Hodges, H.A. 1955. The Pattern of Atonement. SCM.

Klawans, Jonathan. 2006. Purity, Sacrifice, and the Temple: Symbolism and Supersessionism in the Study of Ancient Judaism. Oxford University Press.

Levenson, Jon D. 1993. The Death and Resurrection of the Beloved Son. Yale University Press.

Lewis, David. 2000. "Do we believe in penal substitution?" In Papers in Ethics and Social Philosophy, David Lewis. Cambridge University Press: 128-35.

MacKinnon, D.M. 1966. "Subjective and Objective Conceptions of Atonement." In Prospect for Theology, ed. F.G. Healey. Nisbet.

Martin, Michael. 1991. The Case Against Christianity. Temple University Press. 
McGrath, Alister E. 1985. "The Moral Theory of the Atonement: An Historical and Theological Critique." Scottish Journal of Theology 38.2: 205-20. 1992. What Was God Doing on the Cross? Wipf and Stock.

Marshall, I. Howard. 2007. Aspects of the Atonement. Paternoster.

Milgrom, Jacob. 1991. Leviticus 1-16: A New Translation with Introduction and Commentary. Doubleday.

Moffitt, David. 2013. Atonement and the Logic of Resurrection in the Epistle to the Hebrews. Brill.

Morris, Leon. 1983. The Atonement: Its Meaning and Significance. Intervarsity Press.

Narsai. 1979. "Homily for the Great Sunday of the Resurrection.” In Frederick McLeod, "Narsai's Metrical Homilies on the Nativity, Epiphany, Passion, Resurrection, and Ascension." Patrologia Orientalis 40: 136-61.

O’Collins, Gerald. 2007. Jesus Our Redeemer: A Christian Approach to Salvation. Oxford University Press.

Paul, Robert S. 1960. The Atonement and the Sacraments. Abingdon.

Pelikan, Jaroslav. 1978. The Growth of Medieval Theology; vol.3 of The Christian Tradition. University of Chicago Press.

Porter, Steven L. 2004. "Swinburnian Atonement and the Doctrine of Penal Substitution." Faith and Philosophy 21.2: 228-241.

Purves, Andrew. 2015. Exploring Christology \& Atonement. Intervarsity Press.

Radzik, Linda. 2009. Making Amends: Atonement in Morality, Law, and Politics. Oxford University Press).

Rashdall, Hastings. 1920. The Idea of Atonement in Christian Theology. Macmillan.

Riviere, J. 1909. The Doctrine of the Atonement, vol. 1. Kegan Paul.

Rutledge, Fleming. 2015. The Crucifixion: Understanding the Death of Jesus Christ. Eerdmans.

Schreiner, Thomas R. 2006. "Penal Substitution View," in Beilby and Eddy 2006: 6798.

Stump, Eleonore. 2003. Aquinas. Routledge.

. 2012. "The Nature of the Atonement." In Reason, Metaphysics, and Mind: New Essays on the Philosophy of Alvin Plantinga, ed. Kelly James Clark and Michael Rea. Oxford University Press.

Swinburne, Richard. 1989. Responsibility and Atonement. Oxford University Press. 
Thurow, Joshua C. 2015. “Communal Substitutionary Atonement." Journal of Analytic Theology 3: 47-69.

_ 2017. "Finding Collective Sin and Recompense in Anselm's Cur Deus Homo." American Catholic Philosophical Quarterly 91.3: 431-446.

Turner, H.E.W. 1952. The Patristic Doctrine of Redemption. Wipf and Stock.

Weingart, Richard E. 1970. The Logic of Divine Love. Oxford University Press. 